\title{
Do Finns Date? \\ Cultural Interpretations of Romantic Relating ${ }^{1}$
}

\author{
Saila Poutiainen $^{2}$ \\ University of Helsinki
}

\begin{abstract}
Dating, the stage in American romantic relationships, is a popular theme in interpersonal communication research. This article claims that dating is a cultural construct and concept. The claim is supported by two means: (1) by examining the perceptions of relationships, communication, and personhood that are embedded in American women's interviews, and (2) by comparing these perceptions with Finnish women's interviews about relationship initiation. The cultural meanings of dating should be acknowledged when making generalizations and building theoretical constructs on romantic relationships, as well as in applying American research results in describing Finnish romantic relationships.
\end{abstract}

Keywords: Interpersonal communication, romantic relationships, dating, culture, Finland.

On starting my doctoral studies in the United States, I attended an orientation program for international students, which consisted of several sessions. One session was entitled Dating. Our tutors told us, for example, that first there is dating, then comes seeing someone, and in the next phase you are girlfriend and boyfriend. The information on dating was not new to me, since Finnish media consumers are rather familiar with the American dating scene. Yet, living in the United States, I realized that the expectations and meanings given to dating, and gender roles, atmosphere, and communication on a date were not that familiar. My American female friends seemed to have a shared understanding of what a date or dating is, and how to interpret actions on and around dating.

This article focuses on the expressions and discourses around dating. The discourses here are considered cultural (Carbaugh, 2007), containing and re-creating cultural perceptions about being in the world, about communication, and about

\footnotetext{
${ }^{1}$ Earlier versions of the article have been published and presented as follows: An article in Finnish in Puhe ja kieli in 2005, and presentations at the Annual Conventions of International Communication Association in 1998 in Jerusalem, Israel, and in 1999 in Seattle, WA.

2 Mailing address: Department of Speech Sciences, PO Box 9, 00014 University of Helsinki, Finland

E-mail: saila.poutiainen@ helsinki.fi - Telephone: +358 445292322
} 
relationships. In general, the path between cultural perceptions and interpersonal relationships is not heavily traveled. An ethnographer of communication, Kristine Fitch (1998, p. 3), states this means that interpersonal communication research lacks a deeper understanding of the cultural models for, and meanings of, relating. Fitch (1998) introduces the concept interpersonal ideology, by which she means "a set of premises about personhood, relationships and communication around which people formulate lines of action toward others, and interpret others' actions" (p. 182).

In this study, my aim is to shed some light on the Finnish and American interpersonal ideologies by analyzing the ways in which early romantic relationships are discussed in respective countries. A way to examine cultural discourses is to focus on the terms for talk (Carbaugh, 1989), and extending that model, the analysis in this study focuses on the terms given for the early phases of relating. Romantic relationships are not only recreated in interaction between partners, but also in the communication about relating. Duck and Pond (1989, cited in Sprecher \& Duck, 1994) suggest that the basic core of talking is connected to the basic core of human relating, and that research on relating should be approached by examining the talk about relating by those who are in relationships.

The terms for talk framework draws attention to communicative actions identified, named, or described by the cultural terms for communication. The goal is to "to discover the levels of enactment and the types of meanings that these words about speech suggest" (Carbaugh, 1989, p. 94). The analysis of the meanings of the terms leads to the interpretation of the underlying cultural assumptions or messages about personhood, sociability, and communication, even about dwelling and emotion. These messages are inseparable: Messages about communication are intimately related to the messages of personhood and sociality. Here, the model will be loosely applied to examine the ways in which American and Finnish women talk about relating, and the cultural terms and their meanings that they have for the early phases of romantic relating. These terms, as I will show, imply cultural assumptions not only about relating, but also about communication and personhood.

Earlier research has already shown that some of the very core concepts in interpersonal communication, such as communication (Katriel \& Philipsen, 1990), the self and relationship (Carbaugh, 1989), and self-esteem (Miller, Wang, Sandel \& Cho, 2002), are cultural constructs. In addition to relationships and communication, the feeling of romantic love also seems to have a cultural face of its own (Jankowiak, 
1995). Jankowiak studied 166 research reports on different cultures and found that concepts and conceptions of romantic love were only found in 148 reports.

In analyzing talk about relating, this study is designed to look at communication and romantic relating from the "natives' point of view" (Geertz, 1983). The aim is to describe communication as it appears and means to the communicators. This commitment is in the core of the ethnography of communication approach (for development of and definitions for the approach, see e.g. Hymes, 1967; Carbaugh, 1995; Leeds-Hurwitz, 2005; Philipsen, 1987). The approach points to the inherent connection between communication and culture.

Finnish communication culture is one of the most widely studied in the field of ethnography of communication. We have come to learn, for example, that silence for Finns is a natural way of being (Carbaugh, Berry \& Nurmikari-Berry, 2006), that an asiallinen (matter-of-fact) communication style is highly appreciated in many public scenes, for example, in education (Wilkins, 2005), or that being in peace (olla rauhassa) is an important value for being (Poutiainen, 2007). The discussion of cultural terms for relating adds on the existing knowledge on Finnish communication culture.

In the following, I will first discuss the American women's conceptions of dating and describe and compare their talk to the literature on American communication culture. After that the Finnish women's conceptions are described and compared to the analysis of the American women's talk, and to the literature on Finnish communication culture.

\section{Method}

In this study, the interpretations on cultural beliefs and values are primarily drawn from interviews with American and Finnish women. It is worth noting that in addition to the interviews, my experiences of living in both countries, fluent knowledge of both languages, and access to mediated and informal interactions on and about romantic relating, in both countries, most likely direct my interpretations.

Both American and Finnish women were interviewed on dating and the early phases of romantic relating, respectively. The interviews can be described as informant interviews (Lindlof \& Taylor, 2002), in which the subjects informed the researcher about key features and processes of the topic. The researcher, however, asked the questions, and was responsible for introducing the topics, themes, or scenes for the interviewees to describe (see Appendix 1 for interview questions). 
I found the women in both countries through my social networks. The interviewees could be described as thoughtful, interested in thinking out loud, talkative, and "savvy social actors" (Lindlof \& Taylor, 2002, p. 177). The women volunteered to discuss their personal experiences, motivations, and possible explanations for their preferences and actions. Eight out of nine interviews, which were about one hour long each and took place at private homes, cafes, or an office, were taped and transcribed for analytical purposes.

\section{Interviews with American Women}

Four women aged 24-31were interviewed. Three were at the time in a committed, long-term romantic relationship, one defined herself as single. All women had personal experiences of dating. Three defined themselves as heterosexual. They were all from and were living in the North East of the United States, and native speakers of American English. Two were interviewed together, and two individually.

The theoretical model of terms-for-talk (Carbaugh, 1989) was loosely applied in the analysis. The model originally suggests that by studying meta-communication terms for communication - the underlying cultural beliefs and values could be analyzed. In this study, the word dating was treated as a cultural term, and analyzed as a term that would reveal messages about relating, communication, and personhood. These messages were sought from the interview data by asking: In the talk about dating and dates, what are the beliefs and values about communication and its role in those actions? Further, what kind of beliefs and values about personhood are present in the talk about dating? And finally, what kind of beliefs can be heard about relating? The interview material was examined carefully for explicit and implicit notions on relating. Earlier research in the field of ethnography of communication directed the observations.

\section{Interviews with Finnish Women}

Five women aged 27-32 were interviewed. Two, at the time of interviewing, were in a committed, long-term romantic relationship, three were single. Four defined themselves as heterosexual. All lived in the Helsinki area, but were born and raised in different parts of Finland. All were native speakers of Finnish.

The interviews (each woman was interviewed individually) were designed to elicit the Finnish women's choices for words and expressions (Briggs, 1986). As a 
native speaker of Finnish I knew there is no equivalent word in Finnish for dating, and thus, interview questions, for example, about initial dating, casual dating, or serious dating, all of which are studied in the area of interpersonal communication (see, for example, Alksnis, Desmarais \& Wood, 1996; Bookwala, 2003; Kalbfleisch, 2001; Laner \& Ventrone, 2000; Sprecher \& Duck, 1994) were close to impossible to translate into Finnish, and would have made no sense for the Finnish interviewees.

The interviews with the Finnish women began with Miten kuvailisit nykyistä parisuhdestatustasi? [How would you describe you current relationship status?] The concept "relationship status" was used to avoid use of any particular cultural terms. Some found this semi-formal term funny, but it turned out to be rather successful: they were able to define their own status in their own words (for example, one interviewee said "Mä kattelen." [I observe.]), and the follow-up questions: Why did you find the question funny?, and What would you normally say? led to fruitful discussions.

The analysis of the Finnish women's talk on the early phases of romantic relating focused on finding the ways in which Finnish women name the early stages of romantic relating. The repetitive words and forms of expressions were collected. The above-mentioned katella [to observe] was repeatedly mentioned, and was brought to the centre of the analysis. All the Finnish interviewees recognized the word, and on later occasions, for example, when introducing the research to different audiences, Finnish speakers frequently recognized the term.

The analysis of the terms used proceeded with similar questions to those in the analysis of the American women talk: the cultural beliefs and values about personhood, communication, and relating were examined in the ways in which Finnish women talk about romantic relating.

\section{What is a date?}

Dell Hymes (1972) has introduced a SPEAKING mnemonic as a tool to portray cultural communication events, and here it will be partly applied to describe a date as a cultural communication event (discussion of channels (I), norms (N), and genres $(\mathrm{G})$ are left for future studies). For the description of this event, I will draw from the interviewees' commentary collected for this study, and from a recent study of Mongeau, Jacobsen, and Donnerstein (2007). In their study, the definitions for dates among undergraduates and single adults were examined. These groups did not differ in their depictions on the structural components of a date, or the first date goals, yet, the single 
adults (representing similar ages and life situations as the American interviewees of this study) had a somewhat more traditional view on dating, the two groups gave somewhat different criteria for choosing dating partners, and single adults more often mentioned marriage or other long-term relationships as a relational outcome (p. 538).

The first letter in the mnemonic stands for the scene or stage (S) of communication, and on a date the scene is usually public. The participants $(\mathrm{P})$ or dating partners go out on a date and they are alone together as a couple in a public place. The partners can be total strangers, acquaintances, or even friends, spending time together. However, if a group of friends spend time together, the event is not considered a date. Mongeau et al. (2007, p. 537) highlight the cognitive aspects on the date definitions. The actual actions on a date are the same as, for example, those with friends (to see a movie, have dinner), but it is in the emotions, goals, and expectations (in cognition) of, the actions where a date gets defined as a date.

The ends (E) or aims of a date could be many. Mongeau et al. (2007) report on first date goals (reducing uncertainty, having fun, relational goals) and that the reports on goals have remained relatively consistent over the years, across groups studied. The interviewees in this study highlighted the evaluation of possible romantic interest as the main motive for a date. The evaluation was described as containing a risk, which increases the emotional and psychological intensity of a date.

The aims (or goals) are achieved by certain actions (A). The actions, in particular, during first-dates are widely recognized and predictable (Rose \& Frieze, 1993; Laner \& Ventrone, 1998; 2000). Often the invitation for a date defines the actions during the date, such as in the example of an invitation provided by an interviewee: "Would you like to get together and see a movie or something?" An invitation to a date, according to the interviewees, is interpreted as containing either romantic interest towards the invitee and/or an interest in getting to know him or her better. Both of these, the expressions of interest and getting to know one another are done in interaction. In the Mongeau et al. study (2007) respondents reported on a certain kind of communication expected on a date: participants mentioned, for example, openness, politeness, and focus on the date partner as features of communication on a date. Key $(\mathrm{K})$ or tone of the interaction in the date event is relaxed, and the participants are, or should be, having fun (Mongeau et al., 2007).

According to the American women interviewed, dating is a phase before a committed relationship or a first or early stage of a committed romantic relationship. Mongeau and Carey (1996) note, however, that it is not necessarily clear for the 
participants whether the first date is a result of the move to the more romantic relating, or whether the relationship takes a romantic turn only after the first date. A romantic relationship almost always requires dating, although dating does not always lead to one.

\section{Cultural Beliefs and Values in the Reports on Dating}

A closer reading of the interview data reveals repeated beliefs and values regarding communication, relating, and being. The beliefs are related to 1) a choicemaking individual, 2) active approach to actions, 3) a requirement to communicate in a relationship, and to 4 ) the right to pursue happiness.

\section{Choices}

The women interviewed attached different choices to dating and to a date. Firstly, as in the following data example, a woman can choose whether she puts herself in a position where dating is possible.

\section{Extract (1)}

I think dating is something people sometimes make themselves do, you know, that goes back to the whole psychological, like, OK, I've been single for long enough, I should date. I should put myself out there, I should take those risks, I should make a move towards meeting someone.

Dating contains other choices too. To agree to go out on a date is also a choice. In addition, the dating partners decide, based on experiences during the dates, whether they are romantically interested in each other, and whether they might possibly want to have another date, with the same person or with others.

The way in which an individual is pictured in the American women's talk as a choice-making individual is similar to Carbaugh's (1989) notions on the individual. He states (1989) that in the middle-American world-view, an individual has the right to choose. He further states that at least partly with the help of, or by making choices, the individual creates his or her freedom, his or her identity, and defines his or her place in the environment while also being responsible for his or her choices. In a similar way an interviewee above (Extract 1) expresses her right to choose by stating that she is ready to "put herself out there". 


\section{Doing Something Actively}

To get to know the romantic partner, or dating, appears in the interviewees' talk as active and goal-oriented practices. In the interviewees' words, to 'get a date' and getting to know someone are talked about as actions in which an individual is an active doer, not, for example, a bystander or someone trusting and believing in destiny.

\section{Extract (2)}

Interviewer: What did she mean by saying I don't wanna date?

Interviewee: [...] deciding not to date, well it means you're not going to actively seek people that you may or may not build relationships with ... spend the energy, spend the time, to go on dates that may flop with the further hope that a few may blossom into a relationship that may or may not be worth anything more than, you know, sex I mean.

Also, getting to know someone is accomplished on a date when partners talk and actively exchange personal information (see also Extract 3). Such talk resonates with the work-metaphor described by Rawlins (1992) and Katriel and Philipsen (1990). They suggest that American relationships and especially their maintenance are sometimes described as work. Katriel and Philipsen (1990, p. 85), in particular, acknowledge that in the United States relationships are "worked on" or "made to work", just like machines, investments, or stakes. An interviewee in this study (Extract 2) used expressions such as "spend the energy, spend the time" and "I should take those risks", which not only refer to work, but also to the economy and costs. To initiate and start a romantic relationship, also dating, is an investment, risk, and a job.

A date is described as an active practice also in the context of initiation dating (see for example Bell \& Roloff, 1991; Rowatt, Cunningham \& Druen, 1999). Before an invitation to a date is extended, one might have spent time actively looking for dates (see Extract 1; see also Rowatt, Cunningham \& Druen, 1999). In order to have a date, an individual could, for example, actively look for and put him or herself in situations and places where the chance of meeting new people is maximized (for example Bell \& Roloff, 1991). Although invitations are traditionally presented by men, an American woman could also initiate a date. 


\section{Communicating in a Relationship}

The women's interview talk about communication and its role in dating and in the beginning of romantic relating reflects earlier research on the meaning of talk and communication in the American life (see for example Carbaugh, 1989). Successful communication is a precondition for a successful date and indicator of poor or unsuccessful communication. One of the important aims on a date is to get to know one another, and to accomplish this goal, spending time alone together, and telling or revealing information about oneself are natural ways (Extracts 3 and 4). If communication on a date is considered poor or if there has been insufficient selfdisclosure or it is unequally distributed, it is likely that the dating partners consider a date to be unsuccessful. Also Sprecher and Duck (1994) note that the quality of communication affects the perceived attraction in dating and friendships.

Extract (3)

Because in an American context you might say well how else am I supposed to, in what other context does it become appropriate for me to learn these things if not spending time alone together, and I think that if I'm on a date and I know it's a date, and I understand that this is the purpose, then I'm ready to reveal things in a way that I otherwise wouldn't.

Here again I want to draw attention to Katriel and Philipsen (1990) and their notions on communication in relating. Katriel and Philipsen (1990) point out that according to the American cultural interpretation in relationships, even in the very fresh ones, one should talk about problems, try to solve them, and be satisfied with the solutions. We could look at dating as including the 'problem' or challenge of finding something in common, and the mutual romantic interest, and acknowledging that. These problems are also solved by talking (Extract 4).

\section{Extract (4)}

Usually for me a bad date is that there's nothing to talk about. I mean for me if we don't hit it off, we don't find something, we don't have to have something in common, we just have to be able to talk to each other. If we can't talk to each other, and there are a lot of silences, and neither of us knows what to say, that's a bad date. 
Carbaugh (1989) describes self-disclosure as a moral imperative. In the American cultural model for communication there are two kinds of self. Communication makes it possible to present oneself to others, and the lack of communication affects the way others experience themselves. Each person is viewed as an individual and the individual almost has a moral obligation to tell others about him or herself (Carbaugh, 1989).

\section{Right to Pursue Happiness}

The talk about dating includes notions on happiness. Earlier Varenne (1977) described American life and he stated that happiness and love unite the American individual to his or her community. Happiness is not possessed by the community or created in a situation, but it is a quality of an individual. The community takes care of the individuals' experiences of happiness. Varenne (1977) states, in a somewhat polemic manner, that happiness in the Unites States is recognizable in two situations: when an individual is married to the right person, and when an individual rightly connects with the group he or she is with (enjoys the action, is relaxed, and takes part). Varenne's (1977) research is based on extensive fieldwork. I hear similar tones in the American women's talk and in Varenne's interpretations: Dating is supposed to make one feel good, it is supposed to create joy, and is done to have fun. In addition, it can be argued that the ultimate aim in dating often is to get married to the right person. In this way an attempt to find dates appears as an attempt to find and accomplish a romantic relationship, which, in the end, leads to marriage, which, in the end, will lead to happiness.

To sum up, the American woman goes out on dates and understands the world as a place where the initiation of a romantic relationship takes place by spending time together, alone, by talking, self-disclosing, actively taking part, evaluating, and making choices. Each individual has the right to pursue happiness, and marriage, which dating in the end could aim for or lead to, is seen as bringing happiness into one's life.

\section{Comparative Case: Finnish Women's Talk about Dating}

Only a few academic texts discuss Finnish romantic relationship initiations. However, going steady, romantic love, and relationships have been studied in many disciplines from different perspectives, for example, in ethnology and folklore studies 
(Hatakka, 1999, 2005; Pöysä \& Siikala, 1998), psychology (Määttä, 1997a, 1997b), cultural studies (Paunonen \& Suominen, 2004), and linguistics (Tainio, 2001).

As stated earlier, to translate dating into Finnish is somewhat problematic. Seurustelu refers to a committed romantic relationship, such as going steady, but there is no one Finnish word to describe the time in romantic relating before that. A concrete example of the translation challenge is Susanna Paasonen's (2004) article on the guidebooks and fiction stories on Internet dating. Paasonen (2004) writes (translation and underlining SP):

Oppaiden kirjoittajat omaksuvat kouluttajan roolin, kuvailevat ystäviensä tai asiakkaidensa nettiseurusteluun liittyviä kokemuksia ja ongelmia ja neuvovat lukijoita parisuhdeasiantuntijoiden tapaan. Kirjoittajat vahvistavat asiantuntijuuttaan korostamalla omaa kokemustaan nettiseurustelusta: $\underline{\text { Sabol }}$ julistaa seurustelleensa 67:n Internetissä tapaamansa miehen kanssa kahden vuoden aikana. Tällaista yksityisen ja henkilökohtaisen kokemuksen ääntä voidaan pitää itseapuoppaille ominaisena auktorisointikeinona. (p. 24)

The writers of guidebooks adopt the role of educator, describe their friends' and clients' experiences and problems on Internet seurustelu and advise their readers from the position of a relationship expert. The writers validate their expertness by highlighting their own experiences on Internet seurustelu: $\underline{\text { Sabol declares that }}$ over the past two years she has seurustellut with 67 men she met on the Internet. This voice of the private and personal experience could be viewed as a typical manner in gaining authority in the self-help books.

Sabol, in the original text, apparently described her dating experiences. Paasonen (2004) refers to them as seurustelu, and thus, gives a different tone to Sabol's actions: It is very likely that over the two years Sabol did not seurustella with 67 men. If a relationship lasts, on average, ten days, it most likely is not defined as a close, exclusive, romantic relationship. Instead Sabol dated, that is, went out on dates, with 67 different men. But what word should Paasonen have used instead? How to name the being or the time before seurustelu? And most importantly, who do Finnish women talk about? The Finnish interviewees used the following expressions:

hengailla/hengailu to hang out (spoken Finnish, loan word from English, hang out)

käydä kahvilla to go/meet for coffee

katella/kattelu to watch, to observe (spoken Finnish) 
nähdä

olla jotain

pyöriä (yhdessä)

sekoilla/sekoilu

tapailla/tapailu

treffailla/treffailu

törmäillä/törmäily to see (each other or someone)

to be or to have something (for example, niillä on jotain, they

have something)

\author{
to circle around (together) \\ to mess around \\ to meet/see someone \\ to meet, to date (spoken Finnish, loan word from Swedish, träffa) \\ to bump/run into others
}

When two individuals are described as engaging in one of the actions above, both the speaker and listener could assume that the individuals in question were or are in such a state or situation of a relationship in which the committed romantic relationship has not yet begun. At this phase of relating, the two individuals, one or both, are feeling romantic interest toward one another or they are hoping for a romantic relationship. Of the terms listed above, only treffailla specifically or primarily describes actions related to romantic relating, and interestingly, it is a loan word from Swedish. In the following, a Finnish interviewee described tapailu and treffailu as terms that would describe the actions and being before seurustelu (going steady).

Extract (5)

Interviewer: Puhuuks suomalaiset deittaamisesta?

Interviewee: Ei musta puhu

Interviewer: Mitä ne sanoo?

Interviewee: No se on ehkä pikkusen vähän semmonen ongelmallinenki käsite, että tapailla voidaan tai treffaillaan tai jotain, mutta mä muistan sillon ku mä Mikon kanssa rupesin niin ku tapailemaan, niin joku tuli sitte multa kysymään, että ootteeks te yhdessä ja ja mä sanoin, että me tapaillaan.

Interviewer: Mitä sä tarkotit sillä?

Interviewee: Siis mä tarkotin sitä, että me niin ku soitellaan toisillemme ja nähdään ja mennään elokuviin tai teatteriin tai kaljalle. Tämmösiä juttuja. Muttet se oli niin ku mun kehittämä tavallaan termi siihen tilanteeseen, että se, niin ku mä sanoin Mikolle myöhemmin mä kerroin että me tapaillaan, että niin no sehän on ihan hyvin sanottu. Että sitä me ehkä tehdään.

Interviewer: Do Finns talk about deittaaminen?

Interviewee: I don't think so. 
Interviewer: What do they say?

Interviewee: Well it is somehow also a bit of a problematic concept, one can tapailla or treffailla or something, but I remember when I started tapailla with Mikko, then someone asked are you two together and I said that we tapaillaan. Interviewer: What did you mean by that?

Interviewee: I meant that we kind of call each other and see each other and go to the movies or theatre or for a beer. That sort of thing. But it was like a term that I came up with myself for that situation. When I told Mikko later that I told someone that we tapaillaan, [he said] that was well said. That is perhaps what we are doing.

As we examine the listed words in more detail, we can find several similarities in them. For example, hengailla, katella, tapailla, treffailla, or törmäillä describe actions that are ongoing, maybe occasional, not necessarily predictable, even vague, ambiguous, random, and playful. In Finnish grammar, the -ell and -ill suffixes within the verbs denote the continuous tenses. Also, in the words in this form the agency can be hidden or at least more passive: As the activity is ongoing, it does not really have a beginning or an end, and thus, for example, the initiator of the action is not implied in the use of these words. Examining the word kattelu [watch, observe] more closely, we can hear the cultural premises that are embedded in the word. The word is not necessarily recognized by speakers of all Finnish dialects, but in the data of this study, the actions described as kattelu were certainly recognized. Also, I want to stress that although kattelu as an activity or state is widely recognized, it does not precede all Finnish romantic relationships, nor do I assume that every Finn does or has done it.

Kattelu is a form and a means of communication, both verbal and nonverbal. Kattelu could also be a state of mind. For example, the interviewee who stated her relationship status as "mä kattelen" [I observe], most likely referred to the hope that in the near future there would a romantic relationship in the speaker's life with anyone or someone particular - kattelu could be targeted towards one particular individual (olen katellu yhtä työkaveria, in English, I have watched a colleague of mine, or, I have had my eye on my colleague). Whether kattelu includes talk or not, it is a means of acquiring information on the object of kattelu and on the possibility of mutual romantic interest.

\section{Extract (6)}

Interviewer: Jotkut naiset puhuu kattelemisesta ja tarkkailemisesta. 
Interviewee: Nii joo. Jos se on mahdollista. Aivan.

Interviewer: Ootko sä itte tehny semmosta?

Interviewee: Just jossain työpaikkaympäristössä että sitä niinku kiinnostuu ja siinä on se ulkonäkö mikä vaikuttaa. Onpas kivannäkönen. Joo kyl se on totta. Ja sitä seuraa kenen kanssa se liikkuu ja onks se tietysti varattu ja tota onks se hirveen flirtti ja tota

Interviewer: Some women talk about kattelu and tarkkailu

Interviewee: Oh right. If it is possible. Exactly.

Interviewer: Have you done it yourself?

Interviewee: Somewhere at work, you sort get interested in someone and it is the appearance that affects you. How good looking. Yes, it is true. And you follow where he goes and of course is he taken and is he very flirty and um

Kattelu is an action. The women told that they "pitävänsä silmänsä aukiI" [keep their eyes open], "tarkkailevansa mahdollisuuksial" [observe the possibilities], or "tarkkailevansa jotakin" [observe someone]. Kattelu apparently ends when it becomes unnecessary; the potential romantic relationship has been promoted to, for example, tapailemalla [meeting someone], or kattelu could also end if one finds out that the one being observed is already in a relationship. In the following, an interviewee described kattelu that lasted for an exceptionally long time.

Extract (7)

Interviewer: Miten te tapasitte?

Interviewee: Siis sillai mulla oli puhenainen

Interviewer: Välitysmies

Interviewee: Nii. Et olin mä paljon puoltoista vuotta vakoillu miten tää Tuula käyttäytyy tai miten on ja kävi sit samois paikoissa ja sitten sinä iltana ku mä näin sen vihdoin yksin että sillä ei ollu sitä yhtä ystävää mukana niin sitte mä yhdelle Jonnalle vaan puhuin, että voi että toi on ihana tai jotain niin sit se vaan meni puhuun sille tavallaan. ...

Interviewer: Missä paikoissa te näitte?

Interviewee: No diskoissa. Ja sithän mä näin sitä aamuisin metrossa ... me aina osuttiin sitte....

Interviewer: ... sinä aikana ku te tarkkailitte, ni te ette sinä aikana ees puhunu?

Interviewee: Ei. Eikä edes tervehditty. 
Interviewer: Mutta luuleksä että se tiesi että sä tarkkailet?

Interviewee: Joo. Siis kyllä se kuulemma huomas tai sillai ... mutta kyllä mäki tavallaan huomasin, että seki kiinnitti huomiota muhun.

Interviewer: Mistä sen huomas?

Interviewee: Siitä ku se katteli ja nii ai ja hakeutu ehkä sillai että näköetäisyydelle. Että kyllä se on niin suunnitelmallista. Mut sehän olis ennen ku me tavattiin ni se olis tullu juttelemaan mulle itte jo mutta mä olin kuulemma nin vihasen ku myrskyn merkki ku mä luulin että sillä siinä oli jotain muuta.

Interviewer: How did you meet?

Interviewee: I had a spokeswoman.

Interviewer: Go-between

Interviewee: Yes. I had watched for about a year and a half how this Tuula behaves and how she is and I went to the same places and then that night when I finally saw her alone, and she didn't have a particular friend with her, then I talked to my friend Jonna that oh my how wonderful that woman is or something, then she just went to talk to her. ...

Interviewer: Where did you see each other? Interviewee: Well in discos. And then I saw her in the subway in the mornings ... we always got on the same subway train....

Interviewer: ... during that time when you [two] observed, you didn't even talk during that time?

Interviewee: No. Nor even greet each other.

Interviewer: But do you think she knew that you were observing?

Interviewee: Yes. I mean she told me that she had noticed or something ... but I noticed in a way too that she had paid attention to me.

Interviewer: How did you notice that?

Interviewee: That she katteli and oh yes, stood where I could see her. It is so orderly. But she would have, before we met, she would have come to talk to me herself but I looked so mad, like fit to be tied, she told me, because I thought she had someone else.

Kattelu could include expressions of romantic interest. According to an interviewee, kattelu can take place, for example, at work by seeking the company of the person, by finding out a way to get introduced and then greeting, by going out for a 
coffee, by staring, and by smiling. Both the collection of information on the object of interest, and the evaluation of one's own romantic interest could take place by making observations in general, from afar, and by watching.

Watching and observing as part of the relationship initiation can also be found in earlier Finnish life. Siikala (1998) describes an event called katsojaiset ('watchings') taking place in eastern Finland in the 1950s. Young women or girls were sent from their home village to visit their relatives who lived in neighboring villages. The girls were chaperoned by an older female relative, who helped to put the girls 'on show'. The potential fiancés in the village were informed that a house had young women visiting, and the young men were encouraged to go katsomaan [to watch, in this context, to choose] a girl for themselves. Both in kattelu and in katsojaiset, seeing is vital and highlighted as an acceptable and adequate form for communication in romantic relating.

\section{Cultural Values Active in Kattelu}

Interpreting the Finnish women's descriptions of kattelu, I hear notions of independency. In the context of romantic relating, independency is about maintaining one's face (Brown \& Levinson, 1978) in general and one's positive face in particular. Further, remarks on independency resonate with the core Finnish value of independence and autonomy.

Earlier research (Salo-Lee, 1993) suggests that maintenance of one's negative face is a typical feature of Finnish communication culture. Maintenance of a positive face, however, is related to relationship initiation. This conclusion is drawn from the following idea: Expressions of romantic interest usually include the possibility of being rejected. When the positive face is seen as threatened by the acts of rejection and abandonment, avoidance of rejections and abandonment become strategies by which to avoid loss of positive face. In order to avoid rejection, an expression of romantic interest is executed with great consideration. When describing the expression of romantic interest in particular, the interviewees explained that toisesta roikkuminen [hanging onto someone] or perässä juokseminen [chasing someone, running after someone] are something to avoid.

Extract (8)

Mulla ainaki on henkilökohtaisesti semmonen hirvee ylpeys, että minä en kenenkään perässä juokse ja jos ne ei osota sitä [kiinnostusta] ni olkoon sitte. 
I at least have a strong sense of pride so that I do not run after anyone and if they do not express it [interest] then let it be.

Another interviewee, described her romantic interest in a man she knew, was friends with, and with whom she anticipated having a romantic relationship.

\section{Extract (9)}

... mä en haluu, että se saa tietää sitä [että olen vieläkin kiinnostunut], en todellakaan halua, koska se olis kauheen nöyryyttävää, koska roikkua roikkua vaan toisessa koko ajan.

... I don't want that he finds out [that I'm still interested in him], I really don't, because it would be so humiliating, to hang on, hang on the other one all the time.

Another interviewee (Extract 10), on the other hand, connects expressions of strong enthusiasm with interpretations of desperation.

\section{Extract (10)}

Ja jos se toinen on tavallaan liian innokas niin sekään ei oo hyvä. Että sitte tuntuu, että ehkä se on vähän valtajuttuki, että sitte jos toinen on kauheen innokas, niin tuntuu, että ittellä on liikaa valtaa ja se on paljastanu korttinsa ... En oo liian epätoivonen, en oo epätoivonen saadakseni sut, vaan että olen tässä ja olen kiinnostunut, mutta en ole mitenkään ... se saattaa säikyttää sen toisen vielä kaiken kukkuraksi jos kauheen innokas

...If the other one is sort of too enthusiastic, that is not good either. Then you feel that maybe it's a bit about power too, that if the other one is really enthusiastic, then you feel that you have too much power and the other one has played his/her cards ... I'm not too desperate, I'm not desperate to have you, but instead, I'm here and I'm interested, but I'm not ... that might scare the other one off, on top of everything, if you are too enthusiastic ...

To express romantic interest loudly and clearly could create an imbalance of power between the potential partners, and that is something to be avoided. It could be interpreted that the ideal of being equal includes an ideal of an individual who acts and remains independent and autonomous. When individuals are perceived as equal or even, 
the overt enthusiasm, obviousness, and dependency breaks the equality aimed for. When the expressions of romantic interest and descriptions of the situations remain vague, denial of one's romantic interest is possible by challenging the interpretation of one's actions. This further helps to maintain one's positive face, in this case, one's autonomy. This way the threat of losing one's positive face is attached to the threat of losing one's independency and autonomy.

\section{Discussion}

When American and Finnish women's talk is placed side by side, there are interesting observations to be made. The Finnish women discussed independency in relation to the initiation of romantic relating. Quite possibly, upon asking, independency and autonomy are also important values and experiences for the American women. Yet, in this study, independency was only highlighted in the Finnish women's discussion. In the American women's discussion about dating, respectively, communication, the amount and content of the talk were highlighted. Apparently the American woman considers face-to-face interaction and self-disclosure to be meaningful, efficient, and even the only way to get acquainted with others and find out about the romantic interest. The Finnish women's descriptions did not concentrate on talk - face-to-face interactions or talk were not as self-evident and irreplaceable in the relationship initiation. The acquirement of knowledge was described as taking place also nonverbally, such as kattelemalla.

It is interesting that the Finnish women found it difficult to describe relationship initiation. In the Finnish women's talk, the time or state before seurustelu [going steady] was described as unclear, without boundaries, and ambiguous. In the American women's talk, as well as in the interpersonal communication literature, the shared cultural sense of dating and a date is stronger: Patterns of relationship initiation, including the phases before committed romantic relationship, are collectively recognized and shared. Apparently an American woman considers the time, space, communication, and other actions before a committed relationship as structured, containing widely shared multiple signs, and their meanings.

The interpersonal communication literature recognizes stages, phases, or steps in dating and in dating relationships (see for example Rose \& Frieze, 1993). Also the interviewed women, both American and Finnish, described the romantic interest and relationship movements as taking place in phases or stages. Individuals were described 
as moving from an earlier phase or stage to the next one. However, based on this study, we do not know, for example, how many phases, what kinds of public and private expression are embedded in phases, and what kinds of interpretation of, movements in between, or changes in relationships in or in between the phases and stages there are. This is a task for future research.

The research on dating in the field of interpersonal communication is often drawn from some cultural scenes and not others. This is already acknowledged by several scholars (see for example Mongaue et al., 2007). Questionnaires and questions in interviews are typically answered by young, white, middle-class Americans, often college students, who are in good physical and mental health, educated Western individuals who are or will be salaried. Research on romantic relationships focuses on the goals, problems, models, and unique features of these people (Wood, 1995) and their financial and political ideologies (Lannamann, 1991). In some studies on dating the focus has been on culture, which is usually treated as a synonym for nation or an ethnic or racial group. These studies have looked, for example, at the ways in which culture influences adaptation to dating relationship (Yum, 2004) or the Japanese and American university students' ways to refuse direct or indirect suggestions for sex (Goldenberg, Ginexi, Sigelman \& Poppen, 1999). Concepts such as intercultural dating (e.g. Martin, Bradford, Drzewiecka \& Chitgopekar, 2003) or interracial dating (e.g. Harris \& Kalbfleisch, 2000) seem to refer to dating in the United States, taking place between individuals representing different ethnic or racial groups.

The take on culture and communication in this study is different from those above. From the ethnographic approach I have asked, how romantic relationships are discussed, from the point of view of communication, and of the participants who speak, and what are the cultural beliefs and values active in that talk. My preliminary results suggest that in this case American and Finnish women do not consider communication, social relations, or personhood in quite the same manner, but instead, their talk reveal cultural worldviews. These differences in worldviews are to be taken into consideration when designing new studies on romantic relating and when planning to apply theories and models that are developed from data collected only with the American young adults. There are recent developments in internationalizing the academic world of communication scholars for example within academic organizations and publishing. The academic audiences for interpersonal communication research are truly international, not just American, and more articulated cultural commitments of the 
researchers and more critically discussed cultural focus of the research and theories are in order.

\section{Limitations and Future Research}

The study in hand focused on some American and Finnish women's discussion, and therefore any larger conclusions about American and Finnish communication cultures and their differences are beyond this article. However, the analysis suggests that early phases of romantic relating proceed differently, and that there are cultural beliefs and values about romantic relating.

Some of the earlier interpersonal communication research on dating suggests that men and women have, for example, somewhat different goals for first dates such as sexual relating (Mongeau et al., 2007). In this study the focus has only been on women's talk. Further studies should also give voice to men.

It is my interpretation that in the American literature on romantic relating, and even in some theories (Knapp \& Vangelisti, 2005), the connection between dating and marriage is strongly assumed, if not suggested. A suggestion for future research is to extend the analysis of cultural meanings and beliefs of romantic relating to marriage and its meanings. Although marriage as a goal is less clear or outspoken in the current dating scenes in the United States, I believe the connections between dating and, for example, social status, happiness, independency or adulthood are portrayed differently than they are, for example, in Finland when discussing katteleminen.

\section{Conclusion}

In conclusion, the American concept of dating is a cultural concept and conception. The American research on roles, scripts, or importance of verbal communication in relationship initiation should be applied with care to other communication cultures. As a start, the question of how dating in some cultures differs from the American is irrelevant and even more so, quite possibly impossible to answer. We should ask, instead, is there romance or romantic relating in a given culture. If so, from the natives' point of view, how is communication about and in romantic relating shaped, what are the verbal and nonverbal actions and meanings of the actions in romantic relating, and what are the cultural beliefs and values not only about relating, its 
procedures, phases, shapes, scripts, and systems, but also about communication and personhood.

Over the last few years, expressions such as deittaaminen, deittailu, and deitti have entered spoken Finnish. These words are also used in scientific texts (for example, Paunonen \& Suominen, 2004). What are the writers and speakers talking about? I do not believe that dating, as it is described in this study by some American women, has become part of Finnish life. Assumingly similar actions reflect different cultural interpretations of human relationships, men and women, love, and the anticipated and successful interaction, and these values have not become American. One of the tasks and challenges for interpersonal communication researchers is to recognize and carefully report their own and their research subjects' cultural worldviews.

\section{References}

Alksnis, D., Desmarais, S. \& Wood, E. (1996). Gender differences in scripts for different types of dates. Sex Roles, 34, 321-336.

Bell, R.A. \& Roloff, M.E. (1991). Making a love connection: Loneliness and communication competence in the dating marketplace. Communication Quarterly, 39, 58-74.

Bookwala, J. (2003). Being "single and unattached": The role of adult attachment styles. Journal of Applied Social Psychology, 33, 1564-1571.

Briggs, C. (1986). Learning how to ask: A sociolinguistic approach of the role of the interview in social science research. Cambridge: Cambridge University Press.

Brown, P. \& Levinson, S. (1978). Politeness: Some universals in language use. Cambridge: Cambridge University Press.

Carbaugh, D. (1989). Talking American: Cultural discourses on Donahue. Norwood, NJ: Ablex.

Carbaugh, D. (1995). The ethnographic communication theory of Philipsen and associates. In D.P. Cushman \& B. Kovacic (Eds.), Watershed research traditions in human communication theory (pp. 269-297). Albany, NY: SUNY Press.

Carbaugh, D. (2007).Cultural discourse analysis: Communication practices and intercultural encounters. Journal of Intercultural Communication Research, 36, 167-182. 
Carbaugh, D, Berry, M. \& Nurmikari-Berry, M. (2006). Coding personhood through cultural terms and practices: Silence and quietude as a Finnish "natural way of being”. Journal of Language and Social Psychology, 25, 203-220.

Duck, S. \& Pond, K. (1989). Friends, Romans, countrymen, lend me your retrospective data: Rhetoric and reality in personal relationships. Review of Personality and Social Psychology, 10, 3-27.

Fitch, K. (1998). Speaking relationally: Culture, communication, and interpersonal connection. New York: Guildford Press.

Geertz, C. (1983). Local knowledge. Further essays in interpretive anthropology. New York: Basic Books.

Goldenberg, J.L., Ginexi, E.M., Sigelman, C.K. \& Poppen, P.J. (1999). Just say no: Japanese and American style of refusing unwanted sexual advances. Journal of Applied Social Psychology, 29, 889-903.

Harris, T. \& Kalbfleisch, P. (2000). Interracial dating: the implications of race for initiating a romantic relationship. Howard Journal of Communication, 11, 4965.

Hatakka, M. (1999). Seurustelun skeeman tulkinta ja individualismin diskurssi. [Interpretation of the scheme of dating and the discourse of individualism.] Nuorisotutkimus, 3, 3-12.

Hatakka, M. (2005). Heteronormatiivinen parisuhde. Kulttuurisen mallin rakenne ja merkitys kahden suomalaisen omaelämänkerta-aineiston valossa. [Heteronormative romantic relationship. The structure and meaning of the cultural model in two Finnish autobiography data.] Unpublished licenciate thesis. University of Helsinki.

Hymes, D. (1967). Models of the interaction of language and social setting. Journal of Social Issues, 23, 8-28.

Hymes, D. (1972). Models of the interaction of language and social life. In. J.J. Gumperz \& D. Hymes (Eds.), Directions in sociolinguistics: The ethnography of communication (pp. 35-71). New York: Holt, Rinehart \& Winston.

Jankowiak, W. (1995). Introduction. In W. Jankowiak (Ed.), Romantic passion: A universal experience? (pp. 1-19). New York: Columbia University Press. Kalbfleisch, P. (2001). Deceptive message intent and relational quality. Journal of Language and Social Psychology, 20, 214-233.

Katriel, T. \& Philipsen, G. (1990). "What we need is communication": "Communication" as a cultural category in some American speech. In D. 
Carbaugh (Ed.), Cultural communication and intercultural contact (pp. 77-93). Hillsdale, NJ: Lawrence Erlbaum.

Knapp, M.L. \& Vangelisti, A.L. (2005). Interpersonal communication and human relationships. Boston: Allyn and Bacon.

Laner, M. \& Ventrone, N. (1998). Egalitarian daters/traditionalist dates. Journal of Family Issues, 19, 468-478.

Laner, M. \& Ventrone, N. (2000). Dating scripts revisited. Journal of Family Issues, 21, 488-501.

Lannamann, J.W. (1991). Interpersonal communication research as ideological practice. Communication Theory, 1, 179-203.

Leeds-Hurwitz, W. (2005). Ethnography. In K.L. Fitch \& R.E. Sanders (Ed.), Handbook of language and social interaction (pp. 327-353). Mahwah, NJ: Lawrence Erlbaum.

Lindlof, T.R. \& Taylor, B.C. (2002). Qualitative communication research methods. $2^{\text {nd }}$ Edition. Thousand Oaks, CA: Sage.

Martin, J.N., Bradford, L.J., Drzewiecka, J.A. \& Chitgopekar, A.S. (2003). Intercultural dating patterns among young white U.S. Americans: Have they changed in the past 20 years? Howard Journal of Communication, 14, 53-74.

Miller, P., Wang, S., Sandel, T. \& Cho, G.E. (2002). Self-esteem as folk theory: A comparison of European American and Taiwanese mothers' beliefs. Parenting: Science and Practice, 2, 209-239.

Mongeau, P.A. \& Carey, C.M. (1996). Who's wooing whom II? An experimental investigation of date-initiation and expectancy violation. Western Journal of Communication, 60, 195-213.

Mongeau, P., Jacobsen, J. \& Donnerstein, C. (2007). Defining dates and first date goals. Generalizing from undergraduates to single adults. Communication Research, $34,526-547$.

Määttä, K. (1997a). Miten rakkaussuhde kehittyy ja säilyy. [How is a love affair developed and maintained.] Part III. Lapin yliopiston kasvatustieteellisiä julkaisuja B 23. University of Lapland.

Määttä, K. (1997b). Mitä tapahtuu kun rakastuu? Rakastumisprosessi korkeakouluopiskelijoiden, tutkimustiedon ja runoilijoiden näkökulmasta. [What happens when one falls in love? The process of falling in love among university students according to the research and poets.] Part IV. Lapin yliopiston kasvatustieteellisiä julkaisuja B 25. University of Lapland. 
Paasonen, S. (2004). Sääntöjä Marsille ja Venukselle. Nettiromanssin sukupuolitetut käsikirjoitukset [Rules for Mars and Venus. The gendered scripts for Internet romance.] In U. Paunonen \& J. Suominen (Eds.), Digirakkaus (pp. 23-34). Kulttuurituotannon ja maisemantutkimuksen laitoksen julkaisuja II. University of Turku.

Paunonen, U. \& Suominen, J. (Eds.) (2004). Digirakkaus. [Digilove.] Kulttuurituotannon ja maisemantutkimuksen laitoksen julkaisuja II. University of Turku.

Philipsen, G. (1987). The prospect for cultural communication. In L. Kincaid (Ed.), Communication theory: Eastern and Western perspectives (pp. 245-254). Orlando, FL: Academic Press

Poutiainen, S. (2007). Finnish cultural discourses about mobile phone communication. Unpublished doctoral dissertation. University of Massachusetts Amherst.

Pöysä, J. \& Siikala, A.-L. (1998) (Eds.). Amor, genus \& familia. Kirjoituksia kansanperinteestä. [Amor, genus \& familia. Writings on folklore.] Helsinki: Suomalaisen kirjallisuuden seura.

Rawlins, W. (1992). Friendship matters: Communication, dialectics, and the life course. Hawthorne, NY: Aldine de Gruyter.

Rose, S. \& Frieze, I.H. (1993). Young singles' contemporary dating scripts. Sex Roles, 28, 499-509.

Rowatt, W.C., Cunningham, M.R. \& Druen, P.B. (1999). Lying to get a date: The effect of facial physical attractiveness on the willingness to deceive prospective dating partners. Journal of Social and Personal Relationships, 16, 209-223.

Salo-Lee, L. (1993). "Teillä on kaunis nappi" - small talk: tyhjänpuhumista vai mielekästä viestintää. ["You have a beautiful button" - small talk: idle talk or meaningful communication.] In J. Lehtonen (Ed.), Kulttuurien kohtaaminen. Näkökulmia kulttuurienväliseen viestintään (pp. 77-90). Viestintätieteiden laitoksen julkaisuja no. 9. University of Jyväskylä

Siikala, A.-L. (1998). Oliko savolaisilla tunteita? [Did the Savo people have feelings?] In J. Pöysä \& A.-L. Siikala (Eds.), Amor, genus \& familia. Kirjoituksia kansanperinteestä, (pp. 165-192). Helsinki: Suomalaisen Kirjallisuuden Seura.

Sprecher, S. \& Duck, S. (1994). Sweet talk: The importance of perceived communication for romantic and friendship attraction experienced during a getacquainted date. Personal and Social Psychology Bulletin, 20, 391-400. 
Varenne, H. (1977). Americans together: Structured diversity in a Midwestern town. New York: Teachers College Press.

Wilkins, R. (2005). The optimal form: Inadequacies and excessiveness within the asiallinen [matter of fact] nonverbal style in public and civic settings in Finland. Journal of Communication, 55, 383-401.

Wood, J.T. (1995). The part is not the whole: weaving diversity into the study of relationships. Journal of Social and Personal Relationships, 12, 563-567.

Tainio, L. (2001). Puhuvan naisen paikka. Sukupuoli kulttuurisena kategoriana kielenkäytössä. [The pace for a talking woman. Sex/gender as a cultural category in language use.] Helsinki: Suomalaisen Kirjallisuuden Seura.

\section{APPENDIX}

Main interview questions for the American women:

1. Do you date? Have you dated?

2. What is a date?

3. How do you know you are on a date?

4. What is dating?

5. What other terms are there for romantic relationships?

6. What does it mean when someone says: "I've decided not to date", "I'm dating casually", "It wasn't really a date"?

Main interview questions for the Finnish women:

1. Miten kuvailisit nykyistä parisuhdestatustasi?

How would you describe your current relationship status?

2. Jos sinulta kysytään "Seurusteletko?", mitä vastaat?

If somebody asks you "Are you with someone?", what do you answer?

3. Miten teidän/se suhde alkoi?

How did your/that relationship begin?

4. Oliko se tyypillinen alku?Miten suhteet yleensä alkaa?Mitä silloin tapahtuu?

Was it a typical beginning? How do relationships usually begin? What happens then?

5. Mistä tietää että joku on kiinnostunut sinusta?

How do you know if someone is interested in you?

6. Jos haluat osoittaa kiinnostusta, miten se tapahtuu?

If you want to express that you are interested in someone, what do you do?

Received: August 27th, 2009

Accepted: December 30th, 2009 